\title{
The impact of hospitalization on periodontal health status: an observational study
}

\author{
O impacto da hospitalização sobre a condição periodontal: um estudo observacional
}

\author{
Vinícius Aguiar LAGES 1 \\ Thaís Torres Barros DUTRA² \\ Alessandra Noleto de Almeida Nunes LIMA² \\ Regina Ferraz MENDES² \\ Raimundo Rosendo PRADO JÚNIOR²
}

\section{ABSTRACT}

\section{Objective}

To evaluate the impact of hospitalization on the periodontal status of patients admitted to a private hospital.

\section{Methods}

A sample of 41 patients answered a questionnaire on oral hygiene habits before and after hospitalization. An examiner measured the Periodontal Screening and Recording ratio (PSR) within 24 hours after hospitalization (TO), after five (T1) and after ten days of hospital admission (T2).

\section{Results}

47 patients were examined at T0, 37 at T1 and 21 at T2. Between T0 and T1, the periodontal condition of $32.4 \%$ of patients worsened ( $p=$ 0.001). The score of ten patients changed from $P S R=0$ to $P S R=1$ and the score of two changed from PSR $=1$ to $P S R=2$, after 5 days of hospitalization. At T2, 38\% of patients had deteriorated $(p=0.005)$ with 4 developing gingival bleeding and 4 presenting calculus. $19 \%$ of patients $(p=0.046)$ declined between $T 1$ and T2, and 4 patients presented calculus. None of the patients received any guidance on oral hygiene by hospital staff.

\section{Conclusion}

The periodontal condition of hospitalized patients deteriorated over the course of the stay in hospital and, consequently, there was an increased need for treatment. This draws attention to the importance of oral hygiene care in hospital.

Indexing terms: Dental care. Hospitalization. Length of stay. Oral health. Oral hygiene. Periodontal diseases.

\section{RESUMO}

\section{Objetivo}

Avaliar o impacto da internação hospitalar sobre a condição periodontal de pacientes em um hospital privado.

\section{Métodos}

A amostra de 41 pacientes respondeu questionário sobre hábitos de higiene bucal antes e após a internação. Um examinador mensurou o índice Periodontal Screening and Recording (PSR) no início, cinco e dez dias a partir da admissão hospitalar.

\section{Resultados}

Nenhum paciente recebeu orientação sobre higiene bucal por profissionais do hospital. Após 5 dias do exame inicial, 58,8\% dos pacientes sadios apresentaram sangramento à sondagem e 16,7\% dos pacientes com sangramento apresentaram cálculo dental; e 10 dias depois, $70,0 \%$ dos pacientes sadios apresentaram sangramento gengival e $57,1 \%$ daqueles que já tinham sangramento gengival apresentaram cálculo dental. Houve um aumento das necessidades de tratamento.

\section{Conclusão}

A condição periodontal de pacientes internados agravou-se com o decorrer do tempo de internação e, consequentemente, houve um aumento da necessidade de tratamento. Isso desperta a atenção para a importância dos cuidados de higiene bucal no hospital.

Termos de indexação: Assistência odontológica. Hospitalização. Tempo de internação. Saúde bucal. Higiene bucal. Doenças periodontais.

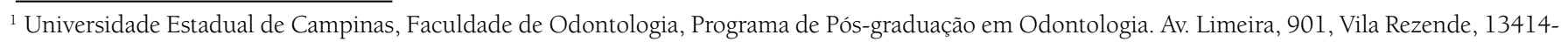
903, Piracicaba, SP, Brasil. Correspondência para / Correspondence to: VA LAGES. E-mail: <viniciusthe@hotmail.com>.

${ }^{2}$ Universidade Federal do Piauí, Programa de Pós-graduação em Clínica Odontológica, Departamento de Odontologia Restauradora. Teresina, PI, Brasil.
} 


\section{INTRODUCTION}

People's attitude toward their oral health is influenced by their personal experiences, which in turn, drive their behavior and perceptions ${ }^{1-4}$. During hospitalization, patients often neglect themselves, feel discouraged and even become physically or mentally incapacitated, and this may adversely affect their performance of oral hygiene care $^{2-9}$. Oral hygiene negligence facilitates the accumulation of microorganisms in the form of biofilm, the etiological agent of oral conditions such as caries and periodontal disease $\mathrm{e}^{8,10-14}$.

The accumulation of biofilm and diversification of the bacterial population increase on a daily basis, eventually leading to the onset of gingivitis, 6,10 . The pathogenic microorganisms of the dental biofilm also have the potential to cause infection or inflammatory processes that impair the functioning of the organs and systems, especially the airways, contributing to increased rates of morbidity and mortality in hospitals ${ }^{11-14}$.

Hospital staff tend to neglect the oral hygiene of hospitalized patients, and concentrate their attention on the main reason for the hospitalization ${ }^{2-3,8}$. Studies evaluating the association between hospitalization and oral health have been conducted, mainly in Intensive Care Units $(I C U)^{6-7,9}$. However, most of the patients are hospitalized in wards where the environment is different to an ICU. Few studies have investigated the oral health of non-ICU patients ${ }^{8}$.

Preexisting oral health conditions of hospitalized patients may deteriorate or other conditions could emerge $^{6-8}$, affecting their quality of life and well-being ${ }^{15-16}$. The aim of this study was to assess periodontal alterations and treatment needs following admission of patients in hospital wards.

\section{METHODS}

This was a longitudinal, observational study that complied with the directions of Brazil's National Health Council Resolution 196/96 and the Declaration of Helsinki (2008) regarding studies involving human beings. The Research Ethics Committee at the Federal University of Piauí, under protocol no. 0126.0.045.000-10, approved this study.

The collection of data took place over a period of 4 months, between January and March 2011, in the
Intensive Care Hospital, a private hospital in Teresina, capital of the Brazilian state of Piauí. A convenience sample was recruited and all the patients occupying beds in the hospital wards were regarded as potential participants in the study.

Patients over 18 years old who agreed to participate and who had been admitted to the hospital within the previous 24 hours were recruited for the study. The reason for the hospitalization was not standardized and, therefore, they were admitted for a variety of causes. The following patients were excluded from the study: those who had been hospitalized for over 24 hours, who were edentulous, unable to complete the form properly, on whom it was not possible to perform an intraoral examination, who were using medication with proven side effects on periodontal tissue, who were undergoing radiotherapy or chemotherapy and those undergoing orthodontic treatment.

The patients' periodontal status was evaluated at three periods, denominated observation periods: TO baseline evaluation, within 24 hours of admission to the hospital; T1 - five days later and T2 - 10 days after baseline. The interval of time used between evaluations was based on the study by Löe et al. ${ }^{10}$, in which it was found that, after five days without oral hygiene, signs of gingivitis were evident. In each observation period, the variables of patients remaining in the study were compared with their own variables recorded in the previous period.

A data collection form was used for socioeconomic variables and to collect information on oral hygiene habits before and after hospitalization. Data regarding the motive and length of hospitalization were obtained from the medical records. The implementation of oral hygiene care during the period of hospitalization, under the guidance or supervision of other health professionals, was also investigated. The assessment of periodontal condition was carried out using the Periodontal Screening and Recording (PSR) system, according to the description of the American Dental Association and American Academy of Periodontology ${ }^{17}$.

The PSR examination was carried out by a single examiner using the probing technique advocated by Wilson Jr. and Magnusson ${ }^{18}$. The examiner was a qualified Periodontist who was calibrated during the examination of six adult patients who were not participants in the study. The patients were evaluated according to the methodology used in the study and re-examined five days later and the intra-examiner agreement index was $82.4 \%$, which was 
considered satisfactory ${ }^{19}$.

The patients in the study were examined while lying down in their hospital beds in a comfortable position, under artificial ceiling lighting, and with a head-torch. The patients were not informed of their periodontal status and no oral hygiene guidance was offered. The annotator filled in the forms containing the periodontal examination results and the examiner was prevented from having access to the information during the period of the study, in order to avoid any bias in the evaluation process.

For the periodontal examination, a Trinity type 621 periodontal probe (São Paulo, SP, Brazil) was used, as recommended by the World Health Organization (WHO). This probe has a spherical tip, $0.5 \mathrm{~mm}$ in diameter and a black band between the $3.5 \mathrm{~mm}$ and $5.5 \mathrm{~mm}$ markers which permits identification of periodontal pockets at this range of depth. The mouth was divided into sextants comprising teeth 17-14, 13-23, 24-27, 37-34, 33-43 and 44-47 and measurements were taken by moving the probe along the gingival sulcus of the teeth in a position parallel to the long axis of each tooth. All the teeth, with the exception of the third molars, were examined at six sites, three buccal and three lingual, recording on an individual record card only the highest scores in each sextant, according to the list below. For each hospitalized patient, only the highest value found among the sextants was considered.

PSR 0: fully visible black band, with no bleeding on probing, absence of calculus or overhanging dental restoration. This score means it is necessary for the patient to adopt suitable preventive measures.

- PSR 1: fully visible black band, but with the presence of bleeding on probing; no calculus or overhanging dental restoration. Treatment needs include the elimination of the supragingival biofilm by the professional and oral hygiene instructions.

- $\quad$ PSR 2: fully visible black band, with absence of periodontal pocket, bleeding on probing, presence of supra and/or subgingival calculus and/or overhanging dental restoration. This requires dental scaling and planning of the tooth surfaces, removal of overhangs, and adequate preventive measures such as oral hygiene instruction.

- $\quad$ PSR 3: partially visible black band, with presence of periodontal pocket between 3.5 and $5.5 \mathrm{~mm}$, indicating the need for additional examinations such as $x$-rays, pocket measurements and level of attachment, among others. Requires specialized periodontal treatment for the patient.
- $\quad$ PSR 4: black band not visible, i.e. totally inside the pocket (presence of periodontal pocket greater than $5.5 \mathrm{~mm}$ ). As it is considered advanced periodontitis, a detailed conventional periodontal examination of the whole mouth is required, with pocket measurements, periodontal chart, and $x$-rays. Requires the need for complex, specialized periodontal treatment.

The PSR scores ranged from 0 to 4 , according to the following criteria and may or may not be associated with an asterisk $(*)$ :

- CODE *: the insertion of code $(*)$ in the sextant signified the presence of problems such as involvement of the root furcation, tooth mobility, loss of attached gingiva and gingival retraction greater than 3.5 $\mathrm{mm}$.

The collected data were analyzed using the software SPSS (Statistical Package for the Social Sciences, Armonk, NY, USA) version 15.0 for Windows. The quantitative variables were evaluated for normality using the Kolmogorov-Smirnov test. For an initial analysis of the data, descriptive percentage statistics were used for all the variables studied. The Wilcoxon test was used to compare the periodontal condition of the observation periods. A confidence interval of $95 \%$ was employed $(p<0.05)$.

\section{RESULTS}

One hundred and seventy six patients were considered for the study; however 129 were not suitable due to the exclusion criteria. The sample consisted of 47 patients who were examined at T0, 37 who remained hospitalized and were examined at $\mathrm{T} 1$ and 21 who remained hospitalized and were examined at $\mathrm{T} 2$. The patients who could not be part of the study were those who: had been hospitalized for over 24 hours $(n=113)$, were edentulous $(n=5)$, did not complete the form properly $(n=3)$, were not able to undergo an intraoral examination $(n=2)$, were using medication with proven side effects on periodontal tissue $(n=2)$, had received radio or chemotherapy $(n=1)$ and were undergoing orthodontic treatment $(n=3) .21$ people advanced to the third phase.

The reasons for the hospitalization of the patients evaluated at T0 were respiratory $(7.5 \%)$, hepatic $(7.3 \%)$, gastric $(7.3 \%)$, metabolic $(9.7 \%)$, intestinal $(12.2 \%)$ and cardiovascular (19.5\%) illnesses, and orthopedic (17.0\%), gynecological $(7.3 \%)$ and plastic $(12.2 \%)$ surgeries. The length of hospitalization varied greatly, between 5 and 
66 days, with an average of 12.8 days. Only 7 patients spent more than 10 days in hospital. Consequently there was a reduction in the number of hospitalized patients at T1 and T2. This occurred due to death, transfer to ICU or discharge.

\section{Sociodemographic characterization}

Most patients (46.9\%) were between 28 and 54 years of age. The majority were females (76.2\%). Regarding their schooling, $14.3 \%$ had completed higher education, $19 \%$ had incomplete higher education, $47.6 \%$ had high school and $14.3 \%$ elementary education. The sample, when distributed by monthly family income, showed the highest concentration (33.3\%) received between 2 and 4 minimum salaries.

\section{Oral health self-care}

Oral hygiene frequency was affected by hospitalization, as shown in Table 1. It was found that all patients brushed their teeth prior to admission to hospital, but $17.1 \%$ stopped brushing after admission. Dental floss usage fell from $40 \%$ to $8 \%$ while in hospital.

Gingival bleeding or toothache during hospitalization was reported by $14 \%$ of patients. However, no patients had their oral cavities examined while in hospital, nor did they receive any guidance about oral hygiene from any professional.

Table 1. Frequency of oral hygiene, before and after admission into a private hospital. Teresina (PI), 2011.

\begin{tabular}{lcc}
\hline $\begin{array}{l}\text { Frequency of } \\
\text { oral hygiene }\end{array}$ & $\begin{array}{c}\text { Before admission } \\
(\%)\end{array}$ & After admission (\%) \\
\hline None & 0.0 & 17.1 \\
Once & 2.1 & 46.8 \\
Twice & 36.2 & 27.6 \\
Three times or more & 61.7 & 8.5 \\
Total & 100.0 & 100.0 \\
\hline
\end{tabular}

\section{Periodontal condition}

Figure 1 shows the distribution of the relative PSR score frequency over the course of hospitalization, at TO, $\mathrm{T} 1$ and $\mathrm{T} 2$.

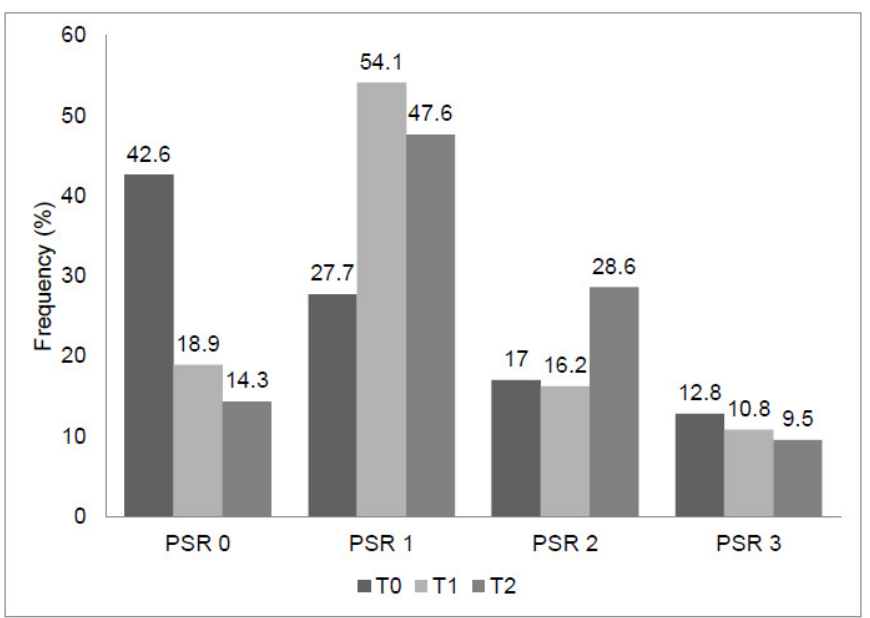

Figure 1. Distribution of patients' PSR, according to period of observation. Teresina (PI), 2011.

Table 2 shows the post-hospitalization periodontal condition. Between T0 and T1, the periodontal condition of $32.4 \%$ of patients deteriorated, with the score of 10 patients changing from $P S R=0$ to $P S R=1$, and two from $P S R=1$ to $P S R=2$, after five days of hospitalization. Only 21 patients remained in hospital until T2 and after 10 days the condition of $38 \%$ of patients worsened, four presenting with bleeding and a further four developing calculus. Between $\mathrm{T} 1$ and $\mathrm{T} 2$, the periodontal health deteriorated in $19 \%$ of patients, as calculus was observed in four patients.

Table 2. Distribution of hospitalized patients according to periodontal condition, per interval of observation. Teresina (PI), 2011

\begin{tabular}{lcccc}
\hline $\begin{array}{l}\text { Periods of } \\
\text { observation }\end{array}$ & $\begin{array}{c}\text { Patients with } \\
\text { unaltered } \\
\text { periodontal } \\
\text { condition }\end{array}$ & $\begin{array}{c}\text { Patients } \\
\text { with } \\
\text { improved } \\
\text { periodontal } \\
\text { condition }\end{array}$ & $\begin{array}{c}\text { Patients with } \\
\text { deterioration } \\
\text { of periodontal } \\
\text { condition }\end{array}$ & $p^{*}$ \\
\hline $\begin{array}{l}\text { T0 to T1 } \\
(n=37)\end{array}$ & 25 & 0 & 12 & 0.001 \\
$\begin{array}{l}\text { T1 to T2 } \\
(n=21)\end{array}$ & 17 & 0 & 4 & 0.046 \\
$\begin{array}{l}\text { T0 to T2 } \\
(n=21)\end{array}$ & 13 & 0 & 8 & 0.005 \\
\hline
\end{tabular}

Note: *Wilcoxon test.

Therefore, the need for periodontal treatment increased as these alterations developed in the periodontal tissues. Four patients remained in $\mathrm{PSR}=3$ at the third examination, possibly because they were already in an advanced stage of periodontal disease since T0. Only two patients had code * recorded, due to gingival recession. 


\section{DISCUSSION}

The periodontal condition of patients in hospital wards worsened, which was observed during or immediately after hospitalization. The periodontal health condition deteriorated after five days, and continued to worsen 10 days after hospitalization.

In this study, negligence of oral health habits was observed among the hospitalized patients. As shown in Table 1, hospitalization caused an impact on the frequency of biofilm removal. There was a significant reduction in the daily frequency of oral hygiene procedures and there was an increase in the percentage of patients who stopped performing these procedures. This outcome was also found in the study by Sousa et al. ${ }^{8}$, who observed the periodontal condition in 162 patients staying in hospital wards for up to 14 days, and found that $72 \%$ of patients reduced their daily frequency of brushing. This change of behavior can contribute to deterioration of oral health status after only a short period of hospitalization. Moreover, the systematic reviews conducted by Sjögren ${ }^{7}$ and Terezakis et al. ${ }^{9}$, both using longitudinal, observational studies in ICUs, suggested deterioration of oral health after hospital admission, with an accumulation of dental biofilm due to a lack of oral hygiene and gingivitis.

Habits such as daily brushing of the teeth and dentures, cleaning of the tongue and use of dental floss were significantly neglected while in hospital. This behavior is probably due to physical or psychological difficulties, demotivation because of the depressive hospital environment and to routines that were totally focused on the illness being treated ${ }^{1-2,5}$. Patients should not be blamed for neglecting their oral health, as they find themselves in need of special care, whether it is related to feeding, accommodation in hospital beds, the administration of medication or of bodily or oral hygiene procedures ${ }^{1-2,4}$.

The number of patients with PSR=0 fell. However, the number with $P S R=1$ and $P S R=2$ increased, i.e. the patients' periodontal health status deteriorated within five to 10 days. The onset of the initial signs of gingivitis (swelling, redness and bleeding gingiva) and the formation of calculus in these patients is related to the accumulation of bacterial biofilm and inadequate oral hygiene over the course of the stay in hospital ${ }^{6,8-9}$.

Calculus is mineralized dental biofilm and the mineralization process begins between the first and fourteenth day after biofilm formation ${ }^{20}$. Calcification of biofilm occurs between four and eight hours ${ }^{21}$ and up to $50 \%$ of biofilm mineralizes in just two days, increasing to
$90 \%$ in 12 days $^{22-23}$. Thus, the period of five days found in this study, regarded as probable for the formation of calculus, is consistent with the timing described in the literature. It should also be stressed that the beginning of calcification and the rate of calculus accumulation vary individually, between different teeth for the same person ${ }^{23}$.

As the formation of periodontal pockets requires a longer exposure to the risk factors ${ }^{10}$, the interval of 10 days was not sufficient for deep pockets to develop. In this context, the length of hospitalization could aggravate the situation, contributing to the evolution of periodontal disease and, consequently, an increase in PSR scores. The longer proper oral hygiene is neglected, the higher the quantity of dental biofilm that will form ${ }^{6,8}$, which could harm the health of patients who are already in a debilitated state $^{8,24}$

A significant worsening of periodontal health was observed for patients with initially good or slightly adverse periodontal health. Needleman et al. ${ }^{6}$, whose observational study with 50 hospitalized patients conducted examinations after one and two weeks of hospitalization, also concluded that the accumulation of biofilm over the course of the stay in hospital was linked to a deterioration in oral health. Similarly, Sousa et al. ${ }^{8}$ examined the oral cavity of hospitalized patients after three, seven and 14 days and came to the same conclusion. The studies included in the systematic review by Sjögren ${ }^{7}$ and Terezakis et al. ${ }^{9}$ assessed patients that were hospitalized for between five and 20 days, and found similar results in terms of deteriorating periodontal condition over the period of hospitalization.

In addition to the aggravation of periodontal disease, there is a bidirectional causality between some diseases of the oral cavity and systemic morbidities, such as cardiovascular and respiratory diseases ${ }^{11,13,25-26}$. The presence of oral biofilm in these patients could trigger an inflammatory response, causing a significant increase in the quantity of immunoglobulin and circulating chemical mediators of inflammation. This phenomenon may have local and remote negative consequences, and should reinforce the initiative for periodontal care of hospitalized patients ${ }^{11-12,14}$.

Hospital health professionals neglected oral healthcare because no attention was given to the oral cavity of hospitalized patients in the study. This scenario is true for many hospitals ${ }^{27-29}$, both public ${ }^{2-4}$ and private ${ }^{3,8}$, due to the scarcity of trained professionals able to get involved in promoting oral healthcare. The training of professionals is a successful practice for reducing infections acquired in hospitals, because they prevent the accumulation of 
bacterial biofilm and the development of periodontal diseases ${ }^{26-28}$

Patients have reported the presence of a dentist on the hospital clinical staff as an important prerequisite for the improvement of their oral condition ${ }^{4}$. The academic training of professionals for insertion into the team of hospital professionals would be beneficial for patients and professionals ${ }^{29}$. Moreover, investment in the implementation of oral healthcare protocols is a measure that should be put in place in hospitals ${ }^{4,8,25-29}$.

The study presented the following limitations: the non-standardization of the reason for hospitalization and the reduced number of patients as the periods of observation progressed. This disadvantage was also present in other studies ${ }^{6,8}$. However, in order to try and minimize these issues, during the analysis of periodontal condition, each individual was compared with himself/herself, in each period of observation, to make the analysis more accurate.

The periodontal health changes observed in the study meant that the treatment needs were also more serious, as in the study by Kumar et al. ${ }^{30}$ Based on the current concept of integrated healthcare and the consequent improvement in people's quality of life, oral care of patients in hospital is essential, given that oral diseases are debilitating and could even develop concomitantly or be associated with systemic diseases ${ }^{12,15-16}$.

It is important to motivate patients to adopt

\section{REFERENCES}

1. Freeman R. The determinants of dental health attitudes and behaviours. Br Dent J. 1999; 187:15-8.

2. Carrilho-Neto A, Ramos S, Sant'Ana ACP, Passanezi E. Oral health status among hospitalized patients. Int J Dent Hyg. 2011 Feb;9(1):21-9. doi: 10.1111/j.1601-5037.2009.00423.x

3. Kahn S, Garcia CH, Galan Júnior J, Namen FM, Machado WAS, Silva Júnior JA, et al. Avaliação da existência de controle de infecção oral nos pacientes internados em hospitais do estado do Rio de Janeiro. Ciênc Saúde Colet. 2008; 13(6):1825-31. doi: $10.1590 / S 1413-81232008000600017$

4. Lima DC, Saliba NA, Garbin AJl, Fernandes LA, Garbin CAS, Fernandes LA. A importância da saúde bucal na ótica de pacientes hospitalizados. Ciênc Saúde Colet. 2011;16(Supl. 1):1173-80. doi: 10.1590/S1413-81232011000700049

5. Maestrelli B, Alberton E, Ribeiro DM, Caldo-Teixeira AS. Adult patients' profile regarding their oral health conditions and behavior. Int J Dent. 2010;9(3):107-13.

6. Needleman I, Hyun-Ryu J, Brealey D, Sachdev M, MoskalFitzpatrick D, Bercades $G$, et al. The impact of hospitalization on dental plaque accumulation: an observational study. J Clin better oral care procedures and encourage hospitals to develop oral health promotion programs ${ }^{27-28}$. This could have a positive impact on morbidity, mortality, time and cost of hospitalization $27,29-30$. The use of mechanical tooth brushing, oral antiseptics and antimicrobials has been shown to modulate the oral microenvironment and reduce the impact of hospitalization on the oral health of patients $^{25-26,28}$.

\section{CONCLUSION}

The periodontal condition of hospitalized patients worsened after their hospital admission and their treatment need increased. Supervision of the periodontal health condition of hospitalized patients is necessary, because these patients tend to neglect their oral hygiene habits and become more susceptible to diseases of the oral cavity.

\section{Collaborators}

VA LAGES, TTB DUTRA and ANAN LIMA participated in the writing of the project, data collection and analysis and article writing. RR PRADO JÚNIOR and RF MENDES idealized the project, outlined the methodology, supervised the data collection stage and participated in the writing and review of the article.

Periodontol. 2012 Nov;39(11):1011-6. doi: 10.1111/j.1600051X.2012.01939.x

7. Sjögren P. Hospitalisation associated with a deterioration in oral health. Evid Based Dent. 2011;12(2):48. doi: 10.1038/ sj.ebd.6400793

8. Sousa LLA, Silva-Filho WS, Mendes RF, Moita-Neto JM, PradoJunior RR. Oral health of patients under short hospitalization period: observational study. J Clin Periodontol. 2014 Jun;41(6):558-63. doi: 10.1111/jcpe.12250

9. Terezakis E, Needleman I, Kumar N, Moles D, Agudo E. The impact of hospitalization on oral health: a systematic review. J Clin Periodontol. 2011 Jul;38(7):628-36. doi: 10.1111/j.1600051X.2011.01727.x

10. Löe $H$, Theilade $E$, Jensen SB. Experimental gingivitis in man. J Periodontol. 1965;36(3):177-87.

11. Linden GJ, Lyons A, Scannapieco FA. Periodontal systemic associations: review of the evidence. J Clin Periodontol. 2013 Apr;40(Suppl 14):S8-19. doi: 10.1111/jcpe.12064

12. Jin $L$, Armitage GC, Klinge $B$, Lang NP, Tonetti $M$, Williams RC. Global oral health inequalities: task group - periodontal disease. Adv Dent Res. 2011 May;23(2):221-6. doi: 10.1177/0022034511402080 
13. Azarpazhooh A, Leake JL. Systematic review of the association between respiratory disease and oral health. J Periodontol. 2006 Sep;77(9):1465-82.

14. Munro CL, Grap MJ, Elswick RK Jr, McKinney J, Sessler CN, Hummel RS. Oral health status and development of ventilatorassociated pneumonia: a descriptive study. Am J Crit Care. 2006 Sep;15(5):453-60.

15. Barbosa TS, Gavião MBD, Mialhe FL. Gingivitis and oral health-related quality of life: a literature review. Braz Dent Sci. 2015;18(1):7-16.

16. Naito $M$, Yuasa $H$, Nomura $Y$, Nakayama $T$, Hamajima $N$, Hanada N. Oral health status and health-related quality of life: a systematic review. J Oral Sci. 2006;11(1):1-7. doi: 10.2334/ josnusd.48.1

17. American Dental Association and American Academy of Periodontology introduce dentists to new time saving periodontal evaluation system. Va Dent J. 1992;69(4):16-7.

18. Wilson Jr TG, Magnusson I. Examination of patients for detect ing periodontal diseases. In: Wilson Jr TG, Kornman KS. Fundamentals of periodontics. Chicago: Quintessence; 1996. p. 195-218.

19. Fleiss JL. Statistical methods for rates and proportions. $2^{\text {nd }}$ ed. New York: John Wiley \& Sons; 1981.

20. Carranza, FA, Newman, MG, Takei, HH, Klokkevold, PR. Periodontia clínica. 11ª ed. Rio de Janeiro: Elsevier; 2011.

21. Tibbets $L$, Kashiva $H$. A histochemical study of early plaque mineralization. Acta Odontol Scand. 1982;40(6):459-66.

22. Muhlemann $\mathrm{H}$, Schroeder H. Dynamics of supragingival calculus formation. Adv Oral Biol. 1964;1:175.

23. Sharawy AM, Sabharwal K, Socransky SS, Lobene RR. A quantitative study of plaque and calculus formation in normal and periodontally involved mouths. J Periodontol. 1966;37(6):495.
24. Da Cruz MK, De Morais N, Trevisani DM. Avaliação clínica da cavidade bucal de pacientes internados em unidade de terapia intensiva de um hospital de emergência. Rev Bras Ter Intensiva. 2014;26(4):379-83.

25. Raghavendran K, Mylotte JM, Scannapieco FA. Nursing homeassociated pneumonia, hospital-acquired pneumonia and ventilator-assisted pneumonia: the contribution of dental biofilms and periodontal inflammation. Periodontol 2000. 2007:44:164-77.

26. Kaneoka A, Pisegna JM, Miloro KV, Lo M, Saito H, Riquelme LF, et al. Prevention of healthcare-associated pneumonia with oral care in individuals without mechanical ventilation: a systematic review and meta-analysis of randomized controlled trials. Infect Control Hosp Epidemiol. 2015 Aug;36(8):899-906. doi: 10.1017/ice.2015.77

27. Godoi APT, Francesco AR, Duarte A, Kemp APT, Silva-Lovato $\mathrm{CH}$. Odontologia hospitalar no Brasil: uma visão geral. Rev Odontol UNESP. 2009; 38(2):105-9.

28. Prendergast $\mathrm{V}$, Kleiman $\mathrm{C}$, King $\mathrm{M}$. The bedside oral exam and the barrow oral care protocol: translating evidence-based oral care into practice. Intensive Crit Care Nurs. 2013;29(5):282-90. doi: 10.1016/j.iccn.2013.04.001

29. Doro GM, Fialho LM, Losekann M, Pfeiff DN. Projeto "Odontologia Hospitalar". Rev Abeno. 2006;6(1):49-53.

30. Kumar M, Chandu GN, Shafiulla MD. Status e tratamento de necessidades de saúde oral em pacientes psiquiátricos institucionalizados: um ano de estudo descritivo transversal. J Dent indiano Res. 2006;17:171-7.

Received on: 2/6/2016

Final version resubmitted on: 12/9/2016 Approved on: 20/12/2016 